\title{
Sprawozdanie z XIV Ogólnopolskiej konferencji naukowej z cyklu „Ekologia humanistyczna” pt. „Paradoksy ekologiczne - odpady miarą sukcesu i porażki cywilizowanej ludzkości" (Warszawa, 28-29.10.2020)
}

\author{
Report on the 14th Polish Conference on the "Humanistic Ecology" Series: \\ "Ecological Paradoxes - Waste as a Measure of Success and Failure of Civilised Mankind" \\ (Warsaw, 28-29 October 2020)
}

\author{
Ryszard F. Sadowski \\ Instytut Filozofii, Uniwersytet Kardynała Stefana Wyszyńskiego w Warszawie \\ ORCID: https://orcid.org/0000-0002-5452-2168・r.sadowski@uksw.edu.pl
}

XIV Ogólnopolska konferencja naukowa pt. „Paradoksy ekologiczne - odpady miarą sukcesu i porażki cywilizowanej ludzkości" jest kolejnym wydarzeniem zorganizowanym przez Wydział Filozofii Chrześcijańskiej UKSW. Inicjatorem cyklu konferencji „Ekologia społeczna”, zapoczątkowanego w 2006 r., był ks. prof. Józef Marceli Dołęga. Cykl ten objął dziesięć konferencji, które odbyły się w latach 2006-2016. Po śmierci ks. prof. J.M. Dołęgi dokonano niewielkiej zmiany profilu konferencji i w roku 2018 zapoczątkowano nowy cykl „Ekologia humanistyczna”. Ze względu na łączność z pierwotnym zamysłem pomysłodawcy i dla uszanowania Jego Osoby postanowiono jednak kontynuować numerację konferencji, stąd tegoroczna konferencja jest już czternastą zorganizowaną przez WFCh UKSW i podejmuje najbardziej aktualne wyzwania środowiskowe.

Problematyka tej konferencji dotyczyła niezwykle ważnego zagadnienia, jakim jest zjawisko gromadzenia, składowania, gospodarowania i przetwarzania odpadów. Dobrze ono ilustruje zarówno miarę dobrobytu materialnego społeczeństw konsumpcyjnych, jak i problemów środowiskowych, wprost proporcjonalnie powiązanych $\mathrm{z}$ tym dobrobytem. Dlatego też tytuł konferencji wskazuje na paradoksy ekologiczne. Pobieżna choćby obserwacja zjawisk wpisanych w kwestię ekologiczną pozwala bowiem dostrzec ich ambiwalentny charakter. Z jednej strony wskazują one kolejne etapy postępu cywilizacyjnego, z drugiej zaś strony stanowią kolejne przestrogi ekologiczne. Taka ambiwalencja jest paradoksalna, ponieważ oznacza, że konsekwencją dążenia człowieka do osiągnięcia sukcesu jest niezamierzona porażka. Ten paradoksalny związek sukcesu i porażki obserwujemy na wielu obszarach funkcjonowania cywilizowanej ludzkości. Odpady są jednym z takich właśnie obszarów.

W zamyśle organizatorów konferencja miała być płaszczyzną spotkania przedstawicieli różnych dziedzin wiedzy i kultury. Od przedstawicieli nauk przyrodniczych począwszy, poprzez przedstawicieli nauk technicznych, społecznych i prawnych, skończywszy na przedstawicielach nauk humanistycznych i nauk o sztuce. Tylko tak interdyscyplinarne spojrzenie na tematykę 
odpadów pozwala bowiem żywić nadzieję na wypracowanie adekwatnych odpowiedzi na pytania o źródła, przejawy i skutki paradoksów ekologicznych oraz znalezienie optymalnego rozwiązania narastających problemów związanych z odpadami.

Pierwotnie konferencja planowana była na 22 kwietnia 2020 r. Ze względu na wybuch pandemii została przeniesiona na 28-29 października 2020 r. Sytuacja epidemiologiczna uniemożliwiła jednak jej organizację w trybie tradycyjnym, także $w$ terminie jesiennym. Organizatorzy zdecydowali więc, że odbędzie się ona w trybie zdalnym i wydłużyli ją na dwa dni, eliminując sesje równoległe, planowane w trybie tradycyjnym. Prelegenci, reprezentujący 17 ośrodków naukowych z całej Polski, wygłosili podczas konferencji łącznie 19 referatów, z tego 8 pierwszego dnia konferencji i 11 kolejnego dnia. W związku z przełożeniem obrad na jesień organizatorzy zdecydowali, że będzie możliwe wydanie monografii konferencyjnej w wersji drukowanej oraz udostępnienie jej $\mathrm{w}$ wersji elektronicznej w wolnym dostępie w dniu konferencji. Publikacja Paradoksy ekologiczne. Odpady miara sukcesu i porażki cywilizowanej ludzkości ukazała się w planowanym terminie nakładem Wydawnictwa Krajowej Szkoły Administracji Publicznej.

Wydarzenie zostało objęte patronatem honorowym przez kilka prestiżowych podmiotów, byli to: Adam Struzik - Marszałek Województwa Mazowieckiego, Andrzej Konieczny - Dyrektor Generalny Lasów Państwowych, Marek Chibowski - Główny Inspektor Ochrony Środowiska oraz Mariusz Zega - Mazowiecki Wojewódzki Inspektor Ochrony Środowiska.

Głównym organizatorem i pomysłodawcą konferencji było Centrum Ekologii i Ekofilozofii na Wydziale Filozofii Chrześcijańskiej UKSW, natomiast jej współorganizatorami byli: Urząd Marszałkowski Województwa Mazowieckiego, Krajowa Szkoła Administracji Publicznej, Lasy Państwowe, Warszawskie Seminarium Aksjologii Administracji, Światowy Ruch Katolików na Rzecz Środowiska oraz Don Bosco Green Allience.
W środę 28 października wygłoszono 8 referatów, obradom przewodniczył ks. prof. Ryszard Sadowski z Instytutu Filozofii UKSW. Referat Paradoksy nowożytnego projektu panowania człowieka nad przyroda autorstwa ks. prof. Zbigniewa Łepki i ks. prof. Ryszarda Sadowskiego z Centrum Ekologii i Ekofilozofii UKSW wprowadził w tematykę obrad.

W ramach sesji środowej referaty wygłosili również:

1. Anna Malinowska (rzeczniczka Lasów Państwowych), Las nie zaśmieca się sam;

2. dr Aleksandra Lewandowska (Wydział Nauk o Ziemi i Gospodarki Przestrzennej UMK w Toruniu), Tendencje w zakresie recyklingu odpadów komunalnych $w$ Polsce $w$ kontekście ekologizacji;

3. prof. Jerzy Śleszyński (Wydział Nauk Ekonomicznych UW), Miernik zawtaszczania przez ludzi produkcji pierwotnej netto;

4. mgr Patrycja Wąglorz (Wydział Nauk Społecznych UŚ w Katowicach), Zrównoważony dialog jako metoda uświadamiania $w$ walce $z$ odpadami;

5. dr Jolanta Pakulska (Instytut Ekonomii i Finansów UKSW w Warszawie) i dr hab. Małgorzata Rutkowska (Wydział Informatyki i Zarządzania Politechnika Wrocławska), Wskaźniki ładu środowiskowego w zakresie odpadów jako element zrównoważonego rozwoju Unii Europejskiej;

6. ks. dr Łukasz Marczak (Wydział Nauk Społecznych UPJP II w Krakowie), Paradoks socjalizacji gospodarowania zasobooszczędnego;

7. prof. Krystyna Najder-Stefaniak (Wydział Nauk Socjologicznych i Pedagogiki SGGW w Warszawie), Odpady z perspektywy myślenia ekosystemowego.

Czwartkowej (29 października) sesji konferencyjnej przewodniczyła dr Agnieszka Klimska z Wydziału Filozofii Chrześcijańskiej UKSW. Sesja ta objęła aż jedenaście wystąpień: 
1. prof. Joanna Kostecka (Kolegium Nauk Przyrodniczych, Uniwersytet Rzeszowski), Jak możemy zhumanizować gospodarke odpadami żywności;

2. prof. Tomasz Oszako (Zakład Ochrony Lasu, Instytut Badawczy Leśnictwa i Instytut Nauk Leśnych, Politechnika Białostocka), dr Ireneusz Olejarski (Zakład Ekologii Lasu IBL), prof. Tadeusz Malewski (Pracownia Technik Molekularnych i Biometrycznych, Muzeum i Instytut Zoologii PAN w Warszawie) i prof. Justyna Nowakowska (Instytut Nauk Biologicznych UKSW), Zastosowanie odpadów drzewnych w przywracaniu równowagi biologicznej glebom porolnym;

3. prof. Irena Burzyńska (Instytut Badawczy Leśnictwa), Intensyfikacja produkcji rolniczej a problem odpadów żywnościowych;

4. prof. Tomasz Oszako (Zakład Ochrony Lasu IBL i Instytut Nauk Leśnych, Politechnika Białostocka), dr Ireneusz Olejarski (Zakład Ekologii Lasu IBL), prof. Wiesław Szulc (Instytut Rolnictwa SGGW), prof. Justyna Nowakowska (Instytut Nauk Biologicznych UKSW) i prof. Beata Rutkowska (Instytut Rolnictwa SGGW), Wykorzystanie odpadów (popiołów i fosfogipsów) do rewitalizacji zdegradowanych gleb jako elementu gospodarki o obiegu zamkniętym;

5. prof. Katarzyna Góralczyk (Instytut Nauk Biologicznych UKSW), Paradoksalne skutki odżywiania się człowieka;

6. dr Agata Kosieradzka-Federczyk (Instytut Nauk Prawnych UKSW), Lokalne odpady - globalny problem. Perspektywa środowiskowego prawa międzynarodowego;

7. dr Katarzyna Cichos (Instytut Nauk Prawnych UKSW), Zakaz importu odpadów - perspektywa prawnomiędzynarodowa $w$ odniesieniu do polskiego prawodawstwa;

8. dr Kinga Makuch (Instytut Nauk Prawnych UKSW), Wykorzystanie odpadów na cele energetyczne a cele hierarchii postepowania zodpadami;

9. dr Stefan Jarecki (Wyższa Szkoła Informatyki Stosowanej i Zarządzania w Warszawie), Infrastruktura odpadowa, czy energetyczna? Konkurencja a realizacja wartości środowiskowych;

10. dr Paulina Legutko-Kobus (Zakład Polityki Regionalnej i Lokalnej SGH w Warszawie), Gospodarka cyrkularna jako szansa na nowy model gospodarki odpadami w miastach;

11. dr Anna Matuszewska (Centrum Ekologii i Ekofilozofii UKSW), dr Piotr Wieczorek (Sieć Badawcza Łukasiewicz - Przemysłowy Instytut Motoryzacji w Warszawie), prof. Krzysztof Biernat (Sieć Badawcza Łukasiewicz - Przemysłowy Instytut Motoryzacji) i Adam Hańderek (Handerek Technologies w Warszawie), Tworzywa sztuczne jako surowiec „odnawialny”.

Większość referatów znalazła się w monografii konferencyjnej, dlatego też nie będą one w tym miejscu szczegółowo omawiane. Publikacja jest ogólnodostępna w Internecie, a zatem zainteresowane osoby moga bez trudu zapoznać się z treścią wystąpień zaprezentowanych podczas debaty.

Organizatorzy wyrażają wdzięczność Patronom Honorowym konferencji oraz wszystkim jej uczestnikom za stworzenie życzliwej atmosfery wymiany myśli i wspólnych poszukiwań rozwiązań dla złożonych wyzwań, przed jakimi staje dziś ludzkość. 